\title{
SCALING CONSUMERS' PURCHASE INVOLVEMENT: A NEW APPROACH
}

\author{
Kraigher-Krainer, J.
}

A two-dimensional involvement scale is presented in this paper. The scale is based on a comprehensive model and captures the two antecedent factors of purchase-related involvement, namely whether motivation is intrinsic or extrinsic and whether risk is perceived as low or high. The procedure of scale development and item selection is described. The scale turns out to perform well in terms of validity, reliability, and objectivity despite the use of a small set of items - four each - allowing for simultaneous measurements of up to ten purchases per respondent. The procedure of administering the scale is described so that it can now easily be applied by both scholars and practitioners. Finally, managerial implications of data received from its application, i.e. those that provide insights into possible strategic marketing conclusions, are discussed.

JEL classification: M31

\section{Introduction}

Involvement research is a core discipline in marketing and consumer research. Theorists have been intensively exploring the construct for decades in order to better understand particularly those consumer decisions where people show low cognitive engagement (Rothschild, 1984); (Kassarjian, 1981). For practitioners, the approach has been highly relevant in an attempt to better understand and anticipate the way markets respond to investments in developing, pricing, promoting, and distributing products and services. Today we observe a revived interest in low involvement decisions in the field of "behavioral economics" where researchers challenge their former cognitive orientation recognizing that deciders are, in fact, frequently not maximizers but satisficers, given their bounded capacities (e.g., Simon, 1959).

Correspondingly, an impressive body of literature on the measurement of involvement has been published to date. Given that questionnaires appear to be the most appropriate method of measuring involvement and that scales are the foremost method practitioners have access to, this paper focuses on the introduction and assessment of a new involvement scale.

A first generation of scales "from scratch" encompasses the work of Bloch (1981); Kapferer and Laurent (1985); Lastovicka and Gardner (1979); and Zaichkowski (1985).
Notable "second generation" scales based on the former are those of Jain and Srinivasan (1990); McQuarrie and Munson (1987, 1992); and Mittal (1989). Another stream of research partly linked to the involvement concept portraits involvement as a two-dimensional concept with an emotional and a cognitive dimension (Esch and Levermann, 1995; Ratchford, 1987; Vaughn, 1980, 1986; Weinberg, 1994; Zaichkowsky, 1994).

The most important points of criticism with regard to these scales are: (1) unclear conceptualization (antecedents, involvement, consequences) and lack of differentiation from similar concepts like "personal relevance" (Poiesz and De Bont, 1995); (2) unclear dimensionality of the construct (Jain and Srinivasan, 1990; Mittal, 1989); (3) reduction of the involvement scope from negative vs. positive to neutral vs. positive (Rossiter, Percy, and Donovan, 1991); (4) the application of student samples and one-product-samples in the scale development process (Wells, 1993); (5) resulting scales which are too long for multi-product studies (McQuarrie and Munson, 1992); (6) not excluding respondents which never buy a particular product thus confusing "no involvement/irrelevance" with "low involvement" (Kraigher-Krainer, 2007).

The "RP-Grid" (Percy, 1997; Rossiter and Bellman, 2005; Rossiter, Percy and Donovan 1991) and the "ECID-model" (Kraigher-Krainer, 2007, 2011) propose 
conceptualizations that aim to overcome the abovementioned theoretical shortcomings. Both offer models with a limited set of variables which means, among other advantages, clarity and applicability for practitioners. However, Rossiter and colleagues refuse to measure involvement quantitatively, which makes their model impossible to apply in practice without the help of specially trained people. Thus the scale development is based on Kraigher-Krainer's ECID-model (hence "ECID-scale"). This model postulates that involvement per se is an immeasurable internal state but with two measurable and orthogonal antecedents: Motivation and Perceived Risk (Kraigher-Krainer, 2000, 2007, 2011). The term "ECID" is an abbreviation for the proposed customer decision process of: emotion $\rightarrow$ cognition $\rightarrow$ involvement $\rightarrow$ decision.

The resulting aim and scope of this paper is to present a respective scale which is: (1) based on a clear conceptualization of the involvement construct; (2) easy to apply and thus applicable by practitioners; (3) nonetheless in accordance with scientific standards; (4) validated in multi-customer, multi-product/service settings; (5) validated by the data received from a fresh sample, and; (6) rooted in data gained from real consumers who actually buy the explored products or services.

\section{Methodology}

Scale development follows the contemporary procedure of: (1) comprehensive item collection in order to cover all possible aspects of the construct; (2) item reduction applying exploratory factor analysis to uncover independent factors and bundles of correlated items; (3) application of the reduced item-pool to a fresh sample; (4) confirmatory factor analysis and parameter estimation (as to these standards compare, for instance, Homburg and Giering, 1996). In accordance with the underlying conceptualization of involvement, the item collection encompasses the literature domains of involvement research, motivation research and perceived risk research.

\section{Results}

\section{Study 1}

A set of 96 items can be identified to be repeatedly applied in these domains as measuring antecedents of involvement, involvement per se, or consequences of involvement. These items are included in a questionnaire with random order and polarity. The resulting questionnaire is administered to 109 respondents representative for Central European final consumers recruited in accordance with demographic population quotas balanced in terms of age and gender. In order to cover a scattered pattern of purchases, each respondent is asked to apply the questionnaire to one of five products or services: a holiday trip, yoghurt, magazines, sausages, winter tires and, home insurance. These products and services have been shown to be located at different points in the involvement space in preliminary studies and are relatively frequently purchased. If a respondent does not actually purchase the requested product or service, the interview is continued with another product. As mentioned before, this is important in order to distinguish personal relevance regarding products which are not bought at all (for different reasons) from personal relevance regarding products which are bought, yet with low engagement.

A principal component analysis reveals eight items representing the motivational antecedent of involvement and nine representing the cognitive antecedent. Both criteria, eigenvalue $>1$ and scree-test, reveal two equally strong factors with similar variance explained $\left(\mathrm{MSA}_{\text {total }}=0.883\right.$, lowest Item-MSA $=0.822$; Variance explained after Varimax-Rotation: Factor $1=33.64 \%$, Factor $2=28.87 \%$ ). The four items with the highest loadings [in brackets] on the motivation factor (MOT) are: (1) It has to be done ... I like doing it [0.902]; (2) Unpleasant ... Pleasant [0.884]; (3) It's not my idea of fun ... It's great fun [0.846]; (4) Irritating ... Satisfying [0.847]; Cronbach's $\propto=0.911$; lowest item discrimination $=0.751$, all four items contribute to improving reliability, hence these four items are accepted for further scale development. The four items with the highest loadings [in brackets] on the perceived risk factor (RISK) are: (1) The wrong choice would not be a major problem ... The wrong choice would be very annoying [0.854]; (2) Regardless of what I choose, it has hardly any consequences ... Regardless of what I choose, it has considerable consequences [0.797]; (3) All things considered, you can't really lose much ... All things considered, you stand to lose a lot for various reasons [0.782]; (4) You can't really go wrong ... You can easily make a mistake [0.719]; Cronbach's $\propto=0.855$; lowest item discrimination $=0.602$, all four items contribute to improving reliability, hence these four items are accepted for further scale development.

\section{Study 2}

In the confirmatory study, a fresh sample of 774 respondents is involved, representative for final consumers in Central Europe aged 20-69 years of whom 50 percent are of each sex. Each respondent has to assess his/her involvement according to the purchase of three of the following 19 products or services: magazines, lottery tickets, flowers, 
chocolate bars, holiday trips, cars, TV-sets, mobile phones, sausages, bread, cigarettes, batteries, shoe polish, detergent, wall paint, house insurance, heating material, winter tires, or vacuum cleaner.

A confirmatory factor analysis is applied to the fresh database. After having checked for an identification problem, the scales are fixed by setting the regression weight of the regression equation of both the MOT-factor and the RISK-factor to one. The procedure is calculated in AMOS and reveals the following results: $\mathrm{GFI}=0.955$; AGFI $=0.919 ; \quad \mathrm{NFI}=0.956 ; \quad \mathrm{CFI}=0.959$. These results are altogether satisfactory unless $\chi^{2} / \mathrm{df}=262.90 / 20=13.1$ which is significant - yet probably due to the large sample (e.g., Homburg \& Baumgartner, 1995, p. 166; Homburg $\&$ Giering, 1996, p. 10). The two factors are uncorrelated as postulated by the model (Pearson correlation $r=0.004$; $\mathrm{p}<0.878$ ).

\section{Evaluation of Measures}

\section{Objectivity}

Thanks to the fact that Study 2 was carried out by several groups of interviewers and that the order of products presented to the respondents was systematically varied, a comparison of the results achieved by different groups of interviewers for the same product can be used to both stress the robustness of the questionnaire against order effects and calculate processing objectivity. (The responsibility of the interviewers comprised preparation of the interviews, finding respondents, carrying out the interviews, collecting data and entering it in an excel sheet.) Product-specific results were matched according to their order of appearance (first, second, third place) and interviewer-team. A test for mean-differences between the groups results in insignificant differences for the MOT-factor $(\mathrm{F}=0.517 ; \mathrm{df}=2 ; 471 ; \mathrm{p}<0.597)$ as well as the RISK-factor $(\mathrm{F}=1.981 ; \mathrm{df}=2 ; 471 ; \mathrm{p}<0.139)$. Consequently, the scale shows itself to be reliable despite varying interviewers and order of product presentation.

\section{Reliability}

Applying parallel testing or split half is not available due to the intended limited set of variables, i.e., four each. However, the internal consistency can be computed (as has already been reported of Study 1). In Study 2, the respective results are similar even though applied to a variety of 19 heterogeneous products and services. With regards to the MOT-factor, Cronbach's $\propto$ is 0.878 , the lowest item discrimination is 0.722 , all four items contribute to improving reliability, 37.21 percent of variance is explained. As to the RISK-factor, Cronbach's $\propto$ is 0.850 , the lowest item-to-total is 0.722 , all four items contribute to improving reliability and the variance explained is 34.81 percent.

In order to have a further indicator for reliability, the scale is presented to a convenience sample of 79 students regarding a fresh product (ski or snowboard) and a second time after two to four weeks. 37 questionnaires with complete test-retest data remain for computation. The test-retest-reliability is $\mathrm{r}=0.828$ for MOT $(\mathrm{p}<0.001)$ and $\mathrm{r}=0.821$ for RISK $(\mathrm{p}<0.001)$.

Figure 1: The location of 19 explored products and services in the ECID-grid

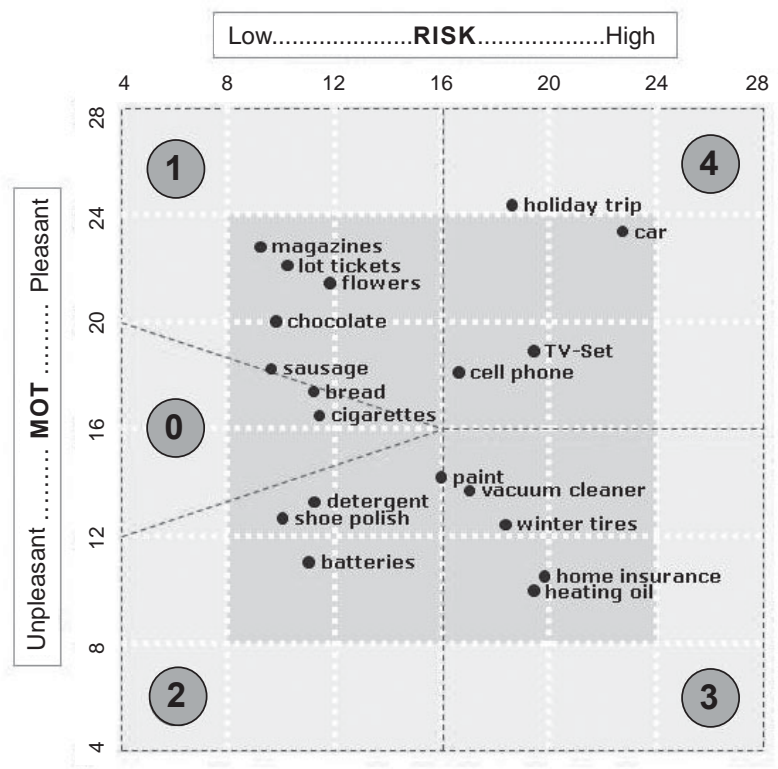

Note that each dimension (MOT and RISK) is measured by 4 items each on a rating-scale from 1 to 7 ; thus the minimum sum is 4 each, and the maximum sum is 28. Rudolph (2008), however, transforms these figures to an index (0-100) which may be more understandable than the range 4-28 applied herein.

\section{Validity}

Face validity addresses the question of whether or not the received data correspond with expected outcomes, i.e., whether low involvement products, impulsive products, or extensive products are located where one would expect them to be. The results correspond strongly with expectations: The ECID scale is the first method to measure impulsive purchases (lottery tickets, magazines, a chocolate bar), extensive purchases (cars, holiday trips), habitual purchases (bread, mineral water) - see Fig. 1, sections 1, 5 and $0-$ and uncovers two further decision types resulting from a specific MOT-RISKcombination in the expected way and as predicted by 
Table 1: Summary of Indicators of the ECID Scale in the Confirmatory Study

\begin{tabular}{|c|c|c|c|}
\hline $\begin{array}{l}\text { Use the following scale to describe your attitude to the purchase } \\
\text { of product/service }\end{array}$ & $\begin{array}{l}\text { MOT } \\
\text { (cFAN) }\end{array}$ & $\begin{array}{c}\text { RISK } \\
\text { (cFAN) }\end{array}$ & $\begin{array}{l}\text { Indicator } \\
\text { Reliability }\end{array}$ \\
\hline 1. You can't really go wrong ... You can easily make a mistake & & 0.71 & 0.51 \\
\hline $\begin{array}{l}\text { 2. All things considered, you stand to lose a lot for various reasons ... } \\
\text { All things considered, you can't really lose much }{ }^{* *}\end{array}$ & & 0.83 & 0.69 \\
\hline $\begin{array}{l}\text { 3. Regardless of what I choose, it has considerable consequences ... } \\
\text { Regardless of what I choose, it has hardly any consequences }{ }^{* *}\end{array}$ & & 0.79 & 0.62 \\
\hline $\begin{array}{l}\text { 4. The wrong choice would be very annoying ... The wrong choice would } \\
\text { not be a major problem ** }\end{array}$ & & 0.74 & 0.55 \\
\hline 5. It's not my idea of fun ... It's great fun & 0.78 & & 0.61 \\
\hline 6. Pleasant ... Unpleasant ** & 0.87 & & 0.76 \\
\hline 7. Irritating ... Satisfying & 0.81 & & 0.65 \\
\hline 8. I like doing it ... It has to be done ${ }^{* *}$ & 0.79 & & 0.62 \\
\hline Average variance explained & $66 \%$ & $59 \%$ & \\
\hline Cronbach's $\propto$ & 0.88 & 0.85 & \\
\hline Test-Retest-Reliability & 0.83 & 0.82 & \\
\hline Factor Intercorrelation & \multicolumn{2}{|c|}{0.000} & \\
\hline MOT-RISK-Intercorrelation & \multicolumn{2}{|c|}{0.004} & \\
\hline
\end{tabular}

* Items 1-4 are summed up to a "Motivation" factor (MOT); items 5-8 are summed up to a "Perceived Risk" factor (RISK).

** Polarity has to be reversed before summing up scores. It is recommended to mix up the eight items and their polarity in order to avoid undesired demand effects.

the ECID- model's "miserly" and "vicarious" purchase types (sections 2 and 3). The results are in correspondence with the underlying model and not one product deviates significantly from its expected location. It is therefore fair to claim face validity.

Nomological validity: In Study 2, respondents are also asked to (1) make an overall assessment of their decision heuristic when it comes to purchasing the given product or service; (2) report the sources of information they prefer as well as (3) the role of informants such as opinion leaders. Again, the results are consistent with the predictions made by the ECID-model. As to convergence and discriminant validity, one indicator supporting its fulfilment is the fact that both factors and sum scores are uncorrelated (as contrasted to, e.g., Zaichkowsky, 1994).

Cross validity can be claimed as the exploratory findings of the first study are validated in the second study using a fresh sample of real consumers and significantly more and different products, reaching from FMCGs to major investments such as cars, insurances, or holiday trips, respectively.

\section{Managerial Implications}

More than ever before, marketers need tools which support them in systematically replacing the product orientated view with a market perceived view of the value a product or service actually provides in the eyes of the customer. This section concentrates on how the ECID-scale can be utilized in terms of strategic decisions for managers from a market based view. As the ECID-scale is easy, short, and immediate, it can be applied as and when needed and in different fields of strategic marketing decisions. It can even be used as a self-administered questionnaire avoiding interviewer effects and making it possible to acquire multiple respondents at the same time without any assistance. Just take the scale, make your own version and let customers and non-customers fill it out while they approach the store. As such, the method does not need expensive research methods. As opposed to other concepts such as the RP-grid it can be used intuitively and without any researcher or consultant. Ten or even more products can be measured supporting marketers in search of assortment understanding and economies of scope. Results can be easily computed and need no "advanced statistics" or "sophisticated interpretations of an expert". Yet it is the goal of the paper to demonstrate that these easy metrics still rest on sound scientific scale standards. Consequently, the last section of the paper offers four possible perspectives for marketers in their attempt to take responsibility in the development of strategic marketing decisions: 
Table 2: Selected Managerial Consequences of Purchase Involvement

\begin{tabular}{|l|l|l|l|l|l|}
\hline $\begin{array}{l}\text { Product category } \\
\text { (see Fig. 1) }\end{array}$ & $\begin{array}{l}\text { Impulsive goods } \\
\text { (Territory 1) }\end{array}$ & $\begin{array}{l}\text { Habitual goods } \\
\text { (Territory 0) }\end{array}$ & $\begin{array}{l}\text { Convenience } \\
\text { goods (Territ. 2) }\end{array}$ & $\begin{array}{l}\text { Unsought goods } \\
\text { (Territory 3) }\end{array}$ & $\begin{array}{l}\text { Specialty goods } \\
\text { (Territory 4) }\end{array}$ \\
\hline $\begin{array}{l}\text { Central } \\
\text { challenge }\end{array}$ & $\begin{array}{l}\text { Experience } \\
\text { leadership }\end{array}$ & $\begin{array}{l}\text { Routine } \\
\text { leadership }\end{array}$ & $\begin{array}{l}\text { Process } \\
\text { leadership }\end{array}$ & $\begin{array}{l}\text { Customer } \\
\text { intimacy }\end{array}$ & $\begin{array}{l}\text { Product } \\
\text { leadership }\end{array}$ \\
\hline $\begin{array}{l}\text { Products and } \\
\text { services }\end{array}$ & $\begin{array}{l}\text { variety seeking, } \\
\text { core product is } \\
\text { entertainment and } \\
\text { surprise }\end{array}$ & $\begin{array}{l}\text { the usual ("my") } \\
\text { product, easy to } \\
\text { identify, automated } \\
\text { purchase }\end{array}$ & $\begin{array}{l}\text { any product will } \\
\text { do, instrumental } \\
\text { or "avoidance" } \\
\text { products }\end{array}$ & $\begin{array}{l}\text { tailored to personal } \\
\text { needs, solves } \\
\text { complex problems, } \\
\text { total solutions }\end{array}$ & $\begin{array}{l}\text { perfect products, } \\
\text { technology push, } \\
\text { customer expertise }\end{array}$ \\
\hline Distribution & $\begin{array}{l}\text { high distribution, } \\
\text { everywhere, POS } \\
\text { and pleasant } \\
\text { atmosphere, nice } \\
\text { people surprise the } \\
\text { customer }\end{array}$ & $\begin{array}{l}\text { reliable, well } \\
\text { known solutions, } \\
\text { no stock outs, } \\
\text { no unnecessary } \\
\text { complication in } \\
\text { assortment }\end{array}$ & $\begin{array}{l}\text { all-around } \\
\text { purchase } \\
\text { opportunities, } \\
\text { everything } \\
\text { that reduces } \\
\text { acquisition costs }\end{array}$ & $\begin{array}{l}\text { company comes } \\
\text { to the customer, } \\
\text { sales team } \\
\text { orientation, } \\
\text { surrogates, high } \\
\text { sales density }\end{array}$ & $\begin{array}{l}\text { exclusive } \\
\text { distribution, } \\
\text { specialized } \\
\text { stores with deep } \\
\text { assortment and } \\
\text { competent clerks }\end{array}$ \\
\hline Type of loyalty & $\begin{array}{l}\text { theme and location } \\
\text { loyalty }\end{array}$ & $\begin{array}{l}\text { loyalty to one's } \\
\text { habits }\end{array}$ & $\begin{array}{l}\text { store and item } \\
\text { loyalty (inertia) }\end{array}$ & $\begin{array}{l}\text { sales rep loyalty, } \\
\text { switching cost } \\
\text { sensitivity }\end{array}$ & brand loyalty \\
\hline
\end{tabular}

Firstly, analyzing the motivation factor of buyers (MOT) reveals the "work-or-fun" orientation of customers: This sheds light on expected assortment, time as investment vs. fun, availability of customers to innovations or the importance of location and accessibility. The general rule is: if people are highly motivated, they are generous with their resources such as time, money, and cognitive effort. They are ready to travel a long way and spend a lot of time in your location. They like assortment, they are open for variety and they will even visit your location without a precise shopping list. The opposite counts for extrinsically motivated customers: here less is more!

Secondly, the perceived risk factor (RISK) uncovers the need for information: It indicates whether there is a demand for information at all - note that managers tend to overestimate this (Levitt, 1960). A better understanding how much information customers actually need has a double effect in that not informing people with a low need for information (a) helps save money and (b) avoids marketing clutter and over-information. If, on the other hand, there is a need for information - indicated by a high RISK-score - this calls for further investigation of the amount and type of information as well as the role of word-of-mouth (WOM) in your business. Mental convenience (e.g., Esch and Rutenberg, 2004) has become a key factor in generating a competitive advantage and ignoring it a key threat (e.g., Iyengar and Lepper, 2000). Estimating the RISK-factor supports marketers in avoiding this strategic challenge.
Thirdly, the combined view provides further insights in terms of the decision heuristic customers are likely to apply to a given product, service, and decision process. Table 2 provides selected managerial aspects where integrating the involvement type of the customer may contribute to a deeper understanding of the feasibility of marketing investments.

Finally, all constructs (MOT, RISK, and involvement) have turned out to be reliable tools for market segmentation and it is apparently one of the key factors to market success. Given that the ECID-scale can be applied to many products at once, it additionally offers an analysis of shopper typologies of your customer database like enthusiasts and lead users as opposed to recreational shoppers or instrumental shoppers in single surveys as well as in continuous customer tracking attempts.

\section{References}

Bloch, P. H. (1981). An Exploration into the scaling of Consumers' Involvement with a product class, in Advances in Consumer Research, Vol. 8, ed. Monroe, K. B., 61-65.

Esch, F.-R., Levermann, T. (1995). Positionierung als Grundlage des strategischen Kundenmanagements auf Konsumgütermärkten. Marketing Review St. Gallen (formerly Thexis), 95 (3): 8-16.

Esch, F.-R., Rutenberg, J. (2004). Mental Convenience beim Einkaufen. Marketing Review St. Gallen (formerly Thexis), 104 (4): 22-26. 
Homburg, C., Baumgartner, H. (1995). Beurteilung von Kausalmodellen. Bestandsaufnahme und Anwendungsempfehlungen. Marketing ZFP, 95 (3): 162-176.

Homburg, C., Giering, A. (1996). Konzeptualisierung und Operationalisierung komplexer Konstrukte. Ein Leitfaden für die Marketingforschung. Marketing ZFP, 96 (1): 5-24.

Iyengar, S. S., Lepper, M. R. (2000). When Choice is Demotivating: Can One Desire Too Much of a Good Thing? Journal of Personality and Social Psychology, 79 (6): 995-1006.

Jain, K., Srinivasan, N. (1990). An Empirical Assessment of Multiple Operationalizations of Involvement, in Advances in Consumer Research, Vol. 17, ed. Goldberg, M. E., Gorn, G. J., Pollay, R., Provo, UT: Association for Consumer Research, 594-602.

Kapferer, J.-N., Laurent, G. (1985). Consumers' Involvement Profile: New Empirical Results, in Advances in Consumer Research, Vol. 12, ed. Hirschman, E. C., Holbrook, M. B., Ann Arbor, MI: Association for Consumer Research, 290-295.

Kassarjian, H. H. (1981). Low Involvement - A Second Look, in Advances in Consumer Research, Vol. 8, ed. Monroe, K. B., Ann Arbor, MI: Association for Consumer Research, 31-34.

Kraigher-Krainer, J. (2000). Käuferverhaltenstypen im Spannungsfeld realer und virtueller Marktplätze, in Zukunftsperspektiven für das Handelsmanagement. Konzepte - Instrumente -Trends, ed. Foscht, T., Jungwirth, G., Schnedlitz, P., Frankfurt/Main: Deutscher Fachverlag, $385-410$.

Kraigher-Krainer, J. (2007). Das ECID-Modell: Fünf Kaufentscheidungstypen als Grundlage der strategischen Unternehmensplanung. Wiesbaden: Gabler.

Kraigher-Krainer, J. (2011). Habit, Affect, and Cognition: A Constructivist Model on How They Shape Decision Making, in Modelling Value. Selected Papers of the 1st International Conference on Value Chain Management, ed. Jodlbauer, H., Olhager, J., Schonberger, R.J., Heidelberg: Physica, 189-206.

Lastovicka, J. L., Gardner, D. M. (1979). Components of Involvement, in Attitude Research Plays for High Stakes, ed. Maloney, J. C., Silverman, B., Chicago: American Marketing Association, 53-73.

McQuarrie, E. F., Munson, J. M. (1987). The Zaichkowsky Personal Involvement Inventory: Modification and Extension, in Advances in Consumer Research, Vol. 14 ed. Wallendorf, M., Anderson, P., Provo, UT: Association for Consumer Research, 36-40.

McQuarrie, E. F., Munson, J. M. (1992). A Revised Product Involvement Inventory: Improved Usability and Validity, in Advances in Consumer Research, Vol. 19, ed. Sherry, J. F., Sternthal, B., Provo, UT: Association for Consumer Research, 108-115.

Mittal, B. (1989). A Theoretical Analysis of Two Recent Measures of Involvement, in Advances in Consumer Research, Vol. 16, ed. Srull, T. K., Provo, UT: Association for Consumer Research, 697-702.
Percy, L. (1997). Strategies for Implementing Integrated Marketing Communications. Chicago: NTC Business Books.

Poiesz, T. B. C., De Bont, C. J. (1995). Do We Need Involvement to Understand Consumer Behavior? in Advances in Consumer Research, Vol. 22, ed. Kardes, F. R., Sujan, M., Provo, UT: Association for Consumer Research, 448-452.

Ratchford, B. T. (1987). New insights about the FCB-Grid. Journal of Advertising Research, 27 (4): 24-38.

Rossiter, J. R., Bellman, S. (2005). Marketing Communication: Theory and Applications. French Forest, NSW: Pearson.

Rossiter, J. R., Percy, L., Donovan, R. J. (1991). A Better Advertising Planning Grid. Journal of Advertising Research, 43 (4): 11-21.

Rothschild, M. L. (1984). Perspectives on Involvement: Current Problems and Future Directions, in Advances in Consumer Research, Vol. 11, ed. Kinnear, T. C., Provo, UT: Association for Consumer Research, 216-217.

Rudolph, T. (2008). Der Schweizer Handel: Konsumententrends 2008. St. Gallen: Thexis.

Simon, H. A. (1959). Theories of Decision Making in Economics and Behavioral Science. American Economic Review, 49 (3): 253-283.

Vaughn, R. (1980). How Advertising Works, A Planning Model. Journal of Advertising Research, 20 (5): 27-33.

Vaughn, R. (1986). How Advertising Works, A Planning Model Revisited. Journal of Advertising Research, 26 (Feb): 57-66.

Weinberg, P. (1994). Emotionale Aspekte des Entscheidungsverhaltens. Ein Vergleich von Erklärungskonzepten. In Konsumentenforschung, München: Forschungsgruppe Konsum und Verhalten, 171-181.

Wells, W. D. (1986). Three useful ideas, in Advances in Consumer Research, Vol. 13, ed. Lutz, R. J., Ann Arbor, MI: Association for Consumer Research, 9-11.

Wells, W. D. (1993). Discovery-oriented Consumer Research. Journal of Consumer Research, 19 (March): 489-504.

Zaichkowsky, J. L. (1985). Measuring the Involvement Construct. Journal of Consumer Research, 12 (Dec.): 341-352.

Zaichkowsky, J. L. (1994). The Personal Involvement Inventory: Reduction, Revision, and Application to Advertising. Journal of Advertising, 23 (4): 59-70.

Priv. Doz. Prof. Dr. Jörg Kraigher-Krainer

Professor of Marketing, Upper Austrian University of Applied Sciences, School of Management Wehrgrabengasse 1-3, 4400 Steyr, Austria

joerg.kraigher@fh-steyr.at 